

\section{EDITORIAL POLICY}

Papers must be submitted with the understanding that they have not been published elsewhere (except in the form of an abstract or as part of a published lecture, review, or thesis) and are not currently under consideration by another journal published or any other publisher. The submitting (Corresponding) author is responsible for ensuring that the article's publication has been approved by all the other coauthors. It is also the authors' responsibility to ensure that the articles coming from a particular institution are submitted with the approval of the necessary institution. Only an acknowledgment from the editorial office officially establishes the date of receipt. It is a condition for submission of a paper that the authors permit editing of the paper for readability. All enquiries concerning the publication of accepted papers should be addressed to ejournal.assist@tau.edu.gy 


\section{ABOUT PLAGIARISM}

Plagiarism is the use or close imitation of the language and ideas of another author and representation of them as one's own original work. Duplicate publication, sometimes called self plagiarism, occurs when an author reuses substantial parts of his or her own published work without providing the appropriate references. This can range from getting an identical paper published in multiple journals, where authors add small amounts of new data to a previous paper.

Plagiarism can be said to have clearly occurred when large chunks of text have been cut and pasted. Such manuscripts would not be considered for publication in EIJASR Journals. But minor plagiarism without dishonest intent is relatively frequent, for example when an author reuses parts of an introduction from an earlier paper. The editors will judge any case of which they become aware (either by their own knowledge of and reading about the literature, or when alerted by referees) on its own merits.

The paper containing the plagiarism will be obviously returned back to the author/s for review, but we earnestly request the authors to avoid submitting plagiarized 


\section{DISCLAIMER}

E-International Journals of Academic \& Scientific Research (EIJASR) make every effort to ensure the accuracy of all the information (the "Content") contained in its publications. However, the EIJASR and its agents make no representations or warranties whatsoever as to the accuracy, completeness or suitability for any purpose of the Content and disclaim all such representations and warranties whether express or implied to the maximum extent permitted by law. Any views expressed in this publication are the views of the authors and are not necessarily the views of the Editor/s or E-International Journals of Academic \& Scientific Research 


\section{TABLE OF CONTENT}

1 Prevalence and Correlates of Depression, Anxiety and Academic Stress among Science Students in Oduduwa University, Ile- Ife, Nigeria

Lamidi Rasheed Emmanuel

2 Knowledge, Attitude and Acceptability of Premarital Genetic Services for Sickle Cell

Disease among Undergraduates of a Nigerian Private Tertiary Institution

Olufisayo. A Bademosi

3 Evaluation of Prevention of Mother to Child Transmission of Human Immunodeficiency 22 Virus Program (Option B+), Kadoma City, Zimbabwe, 2016

Pamela Nyaradzai Magande 


\title{
Prevalence and Correlates of Depression, Anxiety and Academic Stress among Science Students in Oduduwa University, Ile- Ife, Nigeria
}

\author{
Article by Lamidi Rasheed Emmanuel \\ Ph.D. in Public Health, Texila American University \\ Email:adelam77@yahoo.com
}

\begin{abstract}
Background: There is an increasing concern on the mental health of university students worldwide. The objectives of this study are to assess the prevalence and correlates of depression, anxiety and stress among science students of Oduduwa University, Ile-Ife, Nigeria.

Methods: A descriptive cross sectional study design was employed on 367 sampled undergraduate science students of Oduduwa University aged 16-30using sample of convenience. The data was collected usingself-administered questionnaires and data analysis was done using SPSS version 22. The level of significance was set at $p<0.05$.

Results: The prevalence of depression, anxiety and stress among these science students were $62.6 \%, 67.8 \%$ and $17.8 \%$ respectively. Academic performance was found to be significantly associated with depression. Family economic situation was found to be significantly associated with stress. Marginal significant association was found between ethnicity and depression and between parent marital status and stress. No other factors have been found to be significantly associated.

Conclusions: There is a high prevalence of depression, anxiety and stress symptoms among the university students. This stands as a great concern in public health. Therefore, there is need for concerted efforts, preventive measures and sufficient supportive services to be put in place for this group.
\end{abstract}

Keywords: DASS 21, depression, anxiety, stress, university students, Nigeria.

\section{Introduction/Literature review}

University students are regarded as a special group of people that are enduring a critical transitory period in which they are going from adolescence to adulthood which can be seen as one of the most stressful times in a person's life (Eller et al, 2006). The desire to try to fit in, maintain good grades, be away from home and plan for the future often causes anxiety for a lot of students and as a reaction to this stress, some students get depressed and discovered that they cannot get themselves together. Such students may cry all of the time, skip classes or isolate themselves without realizing that they are depressed (Mahmoud et al, 2012).

University students face many problems such as accommodation problems, interpersonal relationships, competition and difficulties in academic studies, economic stress, and struggles with making important decisions (Spiessl et al., 2006; Sobocki et al., 2007). Evidence that suggests that university students are vulnerable to mental health problems has generated increased public concern in Western societies (Stanley and Manthorpe, 2001). Previous studies suggest high rates of psychological morbidity, especially depression and anxiety, among university students all over the world (Stewart-Brown et al., 2000; Tomoda et al., 2000; Ovuga et al., 2006; Wong et al., 2006). Psychological morbidity in undergraduate students represents a neglected public health problem and holds major implications for campus health services and mental policy-making (Royal College of Psychiatrists, 2003; Poch et al., 2004). Therefore, acquiring the understanding of the impact of this neglected public health phenomenon on one's educational attainment and prospective occupational success is very important. Thus, the mental health of university students has been the subject of 
increasing focus in recent years with evidence demonstrating that university students experience higher levels of psychological distress, including anxiety and depression, in comparison to non-student populations (Vaez et al., 2004; Bewick et al., 2010).Moreover, research has shown approximately $40 \%$ of university students with diagnosable mental health conditions do not seek clinical services or access university support services (Gruttadaro and Crudo, 2012).

The prevalence of mental health issues in university students is of universal concern, with international studies revealing clinical levels of psychopathology, including anxiety and depression in student populations globally (Wintre and Yaffe, 2000; Chen, 2013). The prevalence rates of depression range between $11.7 \%$ and $34.4 \%$ in Nigeria (Morakinyo, 2002). Ohaeri and co-workers (1991) reported $49 \%$ at University College Hospital, Ibadan, Nigeria. Some researches show that college-aged students (18-29 year olds) experience a greater prevalence of anxiety compared to the general population (Kessler et al., 2005). Past research, as well, indicates that college students, particularly freshmen, report high levels of stress (DeRosier et al., 2013).

Various socio-demographic characteristics (for example, sex, level of education, and income) are associated with depressive and anxiety disorders. Most studies indicate that sex and socioeconomic status are the most important predictors of these disorders (Regier et al., 1993; Kahn et al., 2000). Moreover, studies have shown that the rates of mental disorders, particularly depression, are associated with various environmental stressors, including family discord (divorce or marital conflict), economic hardship, and stressful life events (Katerndahl and Parchman, 2002; Kessler et al., 2003; Turner and Lloyd, 2004). Some variables such as marital status, urban or rural status, and living arrangements have been found to be related to depressive and anxiety disorders in the literature (Haarasilta et al., 2004; Mirza, 2004) Previous studies showed that below-average income was a risk factor for depressive and anxiety disorders (Mirza, 2004; Muntaner et al., 2004).

Looking at it from the perspectives of public health practice, early detection of mental health problems among young adults in the universities is highly essential in the sense that understanding the psychological distress such as depression, anxiety and stress, as well as their correlates would assist in appropriate screening and intervention programs in order to prevent mental health problems among this population (Shamsuddin et al., 2013).

In Nigeria, epidemiological data about psychological morbidity among undergraduate students are not well-known and there is a paucity of research on prevalence and correlates of depression, anxiety and stress among undergraduate students in Nigerian universities. Hence, the need for this study to fill the gap.

\section{Statement of problem}

Several studies have shown that university students in other part of the world experience high levels of mental health problems such as stress, anxiety and depression. In addition, since early detection and quick prevention of these mental health problems among university students are very important in public health practices, hence, the need for this study to examine prevalence and associated factors of depression, anxiety and stress among university students in my environment.

Furthermore, through my extensive literature search and to the best of my knowledge, there is no formal study conducted on prevalence of depression, anxiety and stress among university students in Ile-Ife and also in Nigeria at large as at the time of conducting this study. Therefore, this study will serve as a baseline study on depression, anxiety and stress among university students in Ile-Ife and in Nigeria. 


\section{Research questions}

The followings were the research questions for this study:

1. What prevalent is depression, anxiety and stress among the science students of Oduduwa University, Ile-Ife, Nigeria?

2. Is there any association between socio demographic variables and depression, anxiety and stress among the science students of Oduduwa University, Ile-Ife, Nigeria?

\section{General objective}

To assess the prevalence andpossible correlates and of depression, anxiety and stress among the science students of Oduduwa University, Ile-Ife, Nigeria.

\section{Specific objectives}

1. To assess prevalence of depression among the science students of Oduduwa University, Ile-Ife, Nigeria.

2. To assess prevalence of anxiety among the science students of Oduduwa University, IleIfe, Nigeria.

3. To assess prevalence of stress among the science students of Oduduwa University, IleIfe, Nigeria.

4. To assess association betweensocio demographic variables (age, gender, ethnicity, living arrangement, academic performance, social life situation, parent marital status, family economic situation)and depression, anxiety and stress among the science students of Oduduwa University, Ile-Ife, Nigeria.

\section{Methodology}

\section{Research design}

A cross sectional descriptive study design was employed for the study and was conducted among undergraduate science students of Oduduwa University, Ile-Ife, Osun State, Nigeria between the period of April and May, 2016.

\section{Study Area}

The study was carried out among the undergraduate students in the college of sciences, Oduduwa University, Ile-Ife, Osun State, Nigeria. Oduduwa University is a well- known and reputable private University located at Ipetumodu (in the Northern part of Ile-Ife), a town in Osun state which is six kilometres $(6 \mathrm{~km})$ away from Ile-Ife. The University was named after Oduduwa, the progenitor of the Yoruba people.

\section{Sampling size determination}

Based on minimum sample size calculation using Leslie and Kish formula for descriptive studies $\mathrm{N}=\mathrm{p}(1-\mathrm{p}) \mathrm{z} 2 / \mathrm{d} 2$ (where $\mathrm{p}$ is the estimated prevalence rate, $\mathrm{z}=1.96$ corresponding to confidence level of $95 \%$ and $d=0.05$ ), sample size was calculated using prevalence rate (p) of 29.3\% (i.e. 0.29) from a previous study (Gan.et al, 2011) and 95\% confidence interval with precision of 5\% to arrive at a total sample size of 316 for this study. To allow for a nonresponse rate of $10 \%$ which is 32 the number of the sample size was then increased to 348 . A total number of 400 questionnaires were then taken to the University to be distributed for the study.

\section{Sampling method}

A convenient sample of 367 science students from Oduduwa University (135 males and 232 females) were successfully interviewed using the questionnaires to record their sociodemographic variables and their responses to the 21 question version of the Depression Anxiety Stress Scale (DASS 21). 
Texila International Journal of Public Health

Volume 4, Issue 3, 2016

\section{Survey instruments and procedures}

Survey instrument for this study consisted of self-administered questionnaire which was divided into two sections: demographic data and Depression Anxiety Stress Scale (DASS 21) questions. Information on socio-demographic data consisted of eight questions based on age groups, ethnicity, gender, living arrangement, academic performance, social life situation, parent marital status and family economic situation were obtained from the participants. The Depression Anxiety Stress Scale (DASS 21) is a 21 item self-reported questionnaire designed to assess and measure the severity of a range of symptoms common to depression, anxiety and stress. The DASS-21 has been well accepted worldwide as a reliable and easy-to-use screening instrument. It is a modified and shorter version of the original version of DASS-42 and it has been reported to have better psychometric properties than DASS-42. In administering the Depression Anxiety Stress Scale, the students were asked to rate the extent to which they have experienced various symptoms over the past one week. Each item was scored on a 4-point Likert scale and each item ranging from 0 (did not apply to me at all over the past one week) to 3 (applied to me very much or most of the time over the past one week).

\section{Data analysis}

A total number of 400 questionnaires were then taken to the University to be distributed for the study A total number of 367 were completed, returned and used for the study (given 37 students as non-respondents). All the completed questionnaires were collated and data processing was performed using Microsoft Excel 2010. All statistical analyses were carried out using the Statistical Package for the Social Sciences, (IBM SPSS software version 22.0). Data analysis for this study involved the use of both descriptive and inferential statistics. Analysis of socio-demographic variables were presented using frequency distributions and percentages. Means and standard deviation were used to present the scores of the outcome variables which are depression, anxiety and stress symptoms scores. Independent sample ttests were used to test the differences in means of depression, anxiety and stress symptom scores by age group and gender variables obtained from the study. One-way ANOVA tests were used to test the significant relationship between ethnicity, living arrangement, academic performance, social life situation, parent marital status, family economic situation and mean depression, anxiety and stress scores. Post Hoc test was then further performed to ascertain which means of each group were significantly different from each other. The level of significance was set at $\mathrm{p}<0.05$.

\section{Ethical consideration}

Permission to conduct the study was sought and obtained from the University. Informed consentwas obtained from every participant and confidentiality was given to them.

\section{Results}

The score ranges of level of severity of DASS scale were shown in Table1. Table 2 showed the socio-demographic variables of these undergraduate science students with their total number and percentages. The total number of undergraduate science students of Oduduwa university that participated in this study were 367 students of which $36.8 \%$ of them were males $(\mathrm{N}=135)$ and $63.2 \%$ were females $(\mathrm{N}=232)$. They were between the ages of 16 and 30 years. Majority of these participants were in the age group 20- 30 years (65.4\%) while others were in the age group 15-19 years (34.6\%). Their mean age was 20.69 years (SD = 2.65). The largest portion of the ethnic group among these students were Yoruba (74.7\%), followed by others (12.8\%), Igbo (10.6\%) and lastly Hausa (1.9\%). Other socio-demographic variables with their total number and percentages were also shown in Table 2. 
Table 1. Level of severity of depression, anxiety and stress

\begin{tabular}{lccc}
\hline Rating & Depression & Anxiety & Stress \\
\hline Normal & $0-9$ & $0-8$ & $0-14$ \\
Mild & $10-13$ & $8-9$ & $15-18$ \\
Moderate & $14-20$ & $10-14$ & $19-25$ \\
Severe & $21-27$ & $15-19$ & $26-33$ \\
Extremely severe & $28+$ & $20+$ & $34+$ \\
\hline
\end{tabular}

Table 2. Descriptive statistics of socio-demographic factors among undergraduate science students (n =397).

\begin{tabular}{lr}
\hline Variables & \multicolumn{1}{c}{$\mathrm{N}(\%)$} \\
\hline Age: & $127(34.6)$ \\
$15-19$ & $240(65.4)$ \\
$20-30$ & \\
Gender: & $135(36.8)$ \\
Male & $232(63.2)$ \\
Female & \\
Ethnicity: & $274(74.7)$ \\
Yoruba & $39(10.6)$ \\
Igbo & $7(1.9)$ \\
Hausa & $47(12.8)$ \\
Others & \\
Living arrangement: & $162(44.2)$ \\
Living with parents & $112(30.4)$ \\
Living with friends/ in hostels & $93(25.4)$ \\
Living alone & $97(26.5)$ \\
Academic Performance: & $97(26.5)$ \\
Highly satisfied & $232(63.3)$ \\
Moderately satisfied & $38(10.2)$ \\
Least satisfied & \\
Social Life Situation: & $102(27.7)$ \\
Highly satisfied & $226(61.6)$ \\
Moderately satisfied & $39(10.7)$ \\
Least satisfied & \\
Parent Marital Status: & $240(65.3)$ \\
Married & $32(8.7)$ \\
Separated/Divorced/Widowed & $95(26.0)$ \\
Never married & \\
Family Economic Situation: & $177(48.2)$ \\
Good & $55(50.4)$ \\
Moderate & $5(1.4)$ \\
Poor & \\
\hline
\end{tabular}

The prevalence of depression, anxiety and stress among undergraduate science students of Oduduwa University were as shown in Table 3. Depression, anxiety and stress are divided into 5 categories of severity namely normal, mild, moderate, severe and extremely severe. Mean \pm standard deviation for depression, anxiety and stress were also displayed in table 3.

Table 4 showed the relationships between socio- demographic factors and mean depression, anxiety and stress scores among the students. No statistical significant relationship was found between age, gender and the mean depression, anxiety and stress scores among the students. Similarly, there was no statistical significant relationship between living arrangement, social life situation and the mean scores of depression, anxiety and stress. 
Texila International Journal of Public Health

Volume 4, Issue 3, 2016

Statistical significant relationship was found between academic performance and the mean depression score only with Post Hoc analysis showing significance difference between students who were least satisfied and those who were moderately satisfied with their academic performance $(\mathrm{F}(2,366)=4.117 ; \mathrm{p}=0.017)$. Also, statistical significant relationship was found between family economic situation and the mean stress score only with Post Hoc analysis showing significance difference between students from good and moderate family economic situation $(F(2,366)=3.247 ; p=0.040)$.

Table 3. Prevalence of depression. Anxiety and stress among undergraduate science students

\begin{tabular}{lr}
\hline Variables & \multicolumn{1}{c}{$\mathrm{N}(\%)$} \\
\hline Depression: & $137(37.4)$ \\
Normal & $79(21.5)$ \\
Mild & $104(28.3)$ \\
Moderate & $30(8.2)$ \\
Severe & $17(4.6)$ \\
Extremely severe & $12.31 \pm 7.18$ \\
Mean \pm Standard Deviation & \\
Anxiety: & $118(32.2)$ \\
Normal & $41(11.1)$ \\
Mild & $95(25.9)$ \\
Moderate & $48(13.1)$ \\
Severe & $65(17.7)$ \\
Extremely severe & $11.83 \pm 8.02$ \\
Mean \pm Standard Deviation & \\
Stress: & $265(72.2)$ \\
Normal & $34(9.3)$ \\
Mild & $44(12.0)$ \\
Moderate & $16(4.3)$ \\
Severe & $8(2.2)$ \\
Extremely severe & $11.02 \pm 8.31$ \\
Mean \pm Standard Deviation &
\end{tabular}


Table 4. Socio- demographic factors and their relationship with depression, anxiety and stress scores.

\begin{tabular}{|c|c|c|c|c|}
\hline Factors & $\mathrm{N}(\%)$ & Depression, mean (SD) & Anxiety, mean (SD) & Stress, mean (SD) \\
\hline All & $367(100.0)$ & $12.31(8.31)$ & $11.83(3.33)$ & $11.02(8.31)$ \\
\hline \multicolumn{5}{|l|}{ Age: } \\
\hline $15-19$ & $127(34.6)$ & $12.61(7.07)$ & $11.75(7.53)$ & $10.96(7.98)$ \\
\hline \multirow[t]{2}{*}{$20-30$} & $240(65.4)$ & $12.15(7.24)$ & $11.88(8.29)$ & $11.05(8.49)$ \\
\hline & & $\mathrm{t}=0.579 ; \mathrm{p}=0.563$ & $\mathrm{t}=-0.144 ; \mathrm{p}=0.886$ & $\mathrm{t}=-0.093 ; \mathrm{p}=0.926$ \\
\hline \multicolumn{5}{|l|}{ Gender: } \\
\hline Male & 135 (36.8) & $11.41(6.44)$ & $11.63(7.17)$ & $10.12(7.53)$ \\
\hline \multirow[t]{2}{*}{ Female } & $232(63.2)$ & $12.83(7.54)$ & $11.95(8.49)$ & $11.54(8.70)$ \\
\hline & & $\mathrm{t}=-1.824 ; \mathrm{p}=0.012$ & $\mathrm{t}=-0.367 ; \mathrm{p}=0.714$ & $\mathrm{t}=-1.583 ; \mathrm{p}=0.101$ \\
\hline \multicolumn{5}{|l|}{ Ethnicity: } \\
\hline Yoruba & $274(74.7)$ & $11.76(6.86)$ & $11.34(7.73)$ & $10.76(7.88)$ \\
\hline Igbo & $39(10.6)$ & $14.97(8.56)$ & $13.85(8.34)$ & $12.51(9.67)$ \\
\hline Hausa & $7(1.9)$ & $13.71(9.89)$ & $10.86(10.51)$ & $12.00(12.11)$ \\
\hline \multirow[t]{2}{*}{ Others } & $47(12.8)$ & $13.01(6.95)$ & $13.19(8.88)$ & $11.11(9.02)$ \\
\hline & & $F(3,366)=2.619 ; p=0.051$ & $F(3,366)=1.663 ; p=0.175$ & $F(3,366)=0.540 ; p=0.655$ \\
\hline \multicolumn{5}{|l|}{ Living arrangement: } \\
\hline Living with parents & $162(44.2)$ & $13.05(7.47)$ & $11.94(8.13)$ & $11.39(8.40)$ \\
\hline Living with friends/ in hostels & $112(30.4)$ & $11.61(6.66)$ & $11.67(7.70)$ & $10.54(8.11)$ \\
\hline \multirow[t]{2}{*}{ Living alone } & $93(25.4)$ & $11.74(7.11)$ & $11.74(8.20)$ & $10.79(8.10)$ \\
\hline & & $F(2,366)=1.657 ; p=0.192$ & $F(2,366)=0.040 ; p=0.961$ & $F(2,366)=0.377 ; p=0.686$ \\
\hline \multicolumn{5}{|l|}{ Academic Performance: } \\
\hline Highly satisfied & $97(26.5)$ & $12.00(7.35)$ & 11.85 (8.89) & $10.44(8.31)$ \\
\hline Moderately satisfied & $232(63.3)$ & $11.87(6.74)$ & $11.51(7.41)$ & $10.94(7.75)$ \\
\hline \multirow[t]{2}{*}{ Least satisfied } & $38(10.2)$ & $15.46(8.80)$ & $14.32(9.32)$ & $13.43(11.35)$ \\
\hline & & $F(2,366)=4.117 ; p=0.017^{*}$ & $F(2,366)=1.957 ; p=0.143$ & $F(2,366)=1.793 ; p=0.168$ \\
\hline \multicolumn{5}{|l|}{ Social Life Situation: } \\
\hline Highly satisfied & $102(27.7)$ & $12.03(7.48)$ & $11.64(8.45)$ & $10.26(8.29)$ \\
\hline Moderately satisfied & $226(61.6)$ & $12.03(6.96)$ & $11.73(7.96)$ & $11.12(8.28)$ \\
\hline Least satisfied & $39(10.7)$ & $14.92(7.25)$ & $13.28(7.26)$ & $11.92(8.42)$ \\
\hline
\end{tabular}


Texila International Journal of Public Health

Volume 4, Issue 3, 2016

Parent Marital Status

$F(2,366)=2.455 ; p=0.087$

Married

Separated/Divorced/Widowed

Never married

$240(65.3)$

$32(8.7)$

95 (26.0)

Family Economic Situation

Good

Moderate

Poor

$177(48.2)$

$185(50.4)$

$5(1.4)$
11.97 (7.49)

$10.88(5.10)$

$13.60(6.86)$

$\mathrm{F}(2,366)=2.455 ; \mathrm{p}=0.087$

$11.52(6.65)$

$12.94(7.62)$

$16.80(5.21)$

$\mathrm{F}(2,366)=2.792 ; \mathrm{p}=0.063$
$F(2,366)=0.699 ; p=0.498$

11.66 (8.13)

$11.00(6.37)$

$12.63(8.27)$

$F(2,366)=0.699 ; p=0.498$

$8.09(0.61)$

$7.97(0.59)$

$9.01(4.04)$

$F(2,366)=0.353 ; p=0.703$
$F(2,366)=2.950 ; p=0.054$

$10.41(8.05)$

$10.19(7.86)$

$12.78(8.93)$

$\mathrm{F}(2,366)=2.950 ; \mathrm{p}=0.054$

$8.27(0.62)$

$8.17(0.60)$

$11.01(4.92)$

$F(2,366)=3.247 ; \mathrm{p}=0.040^{*}$ 


\section{Discussion}

The objective of this study is to assess the prevalence and correlates of depression, anxiety and stress among undergraduate science students of Oduduwa University, Ile-Ife, Nigeria. In this study, the prevalence obtained for the presence of depression, anxiety and stress among these science students were $62.6 \%, 67.8 \%$ and $17.8 \%$ respectively. This showed that prevalence of depression and anxiety are higher in comparison to that of stress among the science students of Oduduwa University, Ile- Ife, Nigeria. This prevalence is higher compared to the one obtained among university students in Turkey where the prevalence of depression, anxiety and stress were found to be $27.1 \%, 47.1 \%$ and $27.0 \%$, respectively (Bayram and Bilgel, 2008). Similarly, the result of this study was also higher than that obtained by Shamsuddin et al (2013) who obtained prevalence of $37.2 \%, 63.0 \%$ and $23.7 \%$ for depression, anxiety and stress respectively in their study among Malaysian university students. This shows that prevalence of depression and anxiety are existing in higher rate among the science students in this study as compared to some other environment outside Nigeria.

In this study, no statistical significant relationship was found between age, gender and the mean depression, anxiety and stress scores among the students. This result is similar to that obtained by Lester (1990) in his study among college students. He reported that significant relationship was found between age and depression scores.In this study, there is no statistical significant relationship between living arrangement, social life situation and the mean scores of depression, anxiety and stress. This result is supported by the one obtained by Shamsuddin et al (2013) who found out that living arrangement had no significant association with mean depression, anxiety and stress scores. Likewise Teh et al (2015) found out that there were no significant association between mean depression and anxiety with social life situation. In this study, there is a significant relationship between family economic situation and the mean stress score. This outcome is supported by Shamsuddin et al (2013) who reported a significant difference in stress score and family income. This study also shows that there is a significant relationship between academic performance and mean depression score but Teh et al (2015) in their study obtained no significant relationship between academic performance and mean depression, anxiety and stress score.

\section{Limitation}

This study has some limitations. The questionnaire was based on self- reported measures. Therefore, the accuracy of the information provided in the questionnaire can be influenced by imprecise self- reports and mistaken perceptions of a situation by the respondents. This limitation was controlled to some extent by making the questionnaire a closed ended type. Secondly, this study is a cross-sectional study in which conclusions about causal relations concerning depression, anxiety and stress among the study population could not be drawn. Also, since the study was conducted in a single university among the science students of the institution, the outcome of this study cannot be generalized on the entire population of all university students in Nigeria.

\section{Conclusion}

This study shows that there is high prevalence of depression, anxiety and stress among undergraduate science students of Oduduwa University, Ile-Ife, Nigeria. This implies that depression, anxiety and stress are neglected public health problems in this institution and can lead to adverse effects on the mental health, quality of life and academic achievement of these students. This study also shows association of depression with academic performance and ethnicity. Finally, in this study, stress was also found to be associated with family economic situation and parent marital status. 
Texila International Journal of Public Health

Volume 4, Issue 3, 2016

\section{Recommendation}

The followings are therefore recommended:

1. There is need for concerted efforts by health care professionals and the university administrative staff to develop appropriate support services catering to this group of students.

2. There is also need for greater attention to the psychological wellbeing of undergraduate students in order to improve their quality of life.

3. Appropriate screening and intervention programs should be allowed especially during orientation so as to prevent mental health problems among students admitted into the universities.

4. Early diagnosis, treatment and counselling as the case may be should be offered to vulnerable students.

\section{References}

[1]. Bayram, $N$ and Bilgel, $N$ (2008). The prevalence and socio-demographic correlations of depression, anxiety and stress among a group of university students. Social Psychiatry and Psychiatric Epidemiology 43, 667-672.

[2]. Bewick B, Koutsopoulou G, Miles J, Slaa E and Barkham M (2010). Changes in undergraduate students' psychological wellbeing as they progress through university. Studies in Higher Education, 35, 633-645. http://dx.doi.org/10.1080/03075070903216643

[3]. Chen L, Wang L, Qiu XH, Yang XX, Qiao ZX, Yang YJ and Liang Y (2013). Depression among Chinese university students: prevalence and socio-demographic correlates. PLoS One, 8, 667-672. http://dx.doi.org/10.1007/s00127-008-0345-x

[4]. DeRosier ME, Frank E, Schwartz V, and Leary KA (2013). The potential role of resilience education for preventing mental health problems for college students. Psychiatric Annals, 43(12): 538544. doi:10.3928/00485713-20131206-05.

[5]. Gruttadaro D and Crudo D (2012). College students speak: a survey on mental health. National Alliance on Mental Health. www.nami.org/namioncampus

[6]. Haarasilta LM, Marttunen MJ, Kaprio JA, Aro HM (2004). Correlates of depression in a representative nationwide sample of adolescents (15-19 years) and young adults (20-24 years). Eur J Public Health; 14:280-285.[7] Kahn RS, Wise PH, Kennedy BP, Kawachi I (2000). State income inequality, household income and maternal mental and physical health: cross sectional national survey. BMJ; 321:311-5.

[7]. Katerndahl DA, Parchman M (2002). The ability of the stress process model to explain mental health outcomes. Compr Psychiatry; 43:351-60.

[8]. Kessler RC, Berglund P, Demler O (2003). The epidemiology of major depressive disorder. JAMA. 289: 3095-105.

[9]. Mahmoud JS, Staten RT, Hall LA, and Lennie TA (2012). "The relationship among young adult college students' depression, anxiety, stress, demographics, life satisfaction, and coping styles,” Issues in Mental Health Nursing, 33 (3): 149- 156.

[10]. Mirza I (2004). Risk factors, prevalence and treatment of anxiety and depressive disorders in Pakistan: a systematic review. BMJ; 328:794-797.

[11]. Monroe ML, Edward PT and Neal HG (1980). Childhood Depression, Family Income, and Locus of Control. Journal of Nervous \& Mental Disease, 168, 732-735.

[12]. Muntaner C, Eaton WW, Miech R, O’Campo P (2004). Socioeconomic position and major mental disorders. Epidemiol Rev; 26:53-62. [14] Ovuga E, Boardman J, Wasserman D (2006). Undergraduate student mental health at Makerere University, Uganda. World Psychiatry, 5(1):51-52

[13]. Poch FV, Villar E, Caparros B, Juan J, Cornella M, Perez I (2004). Feelings of hopelessness in a Spanish university population. Descriptive analysis and its relationship to adapting to university, depressive symptomatology and suicidal ideation. Soc Psychiatry PsychiatrEpidemiol 39:326-334

[14]. Regier DA, Farmer ME, Rae DS, Myers JK, Kramer M, Robins LN (1993). One-month prevalence of mental disorders in the United States and sociodemographic characteristics: the Epidemiologic Catchment Area study. ActaPsychiatrScand; 88(1):35-47. 
[15]. Selye, H. (1978). The stress of life. New York, NY: McGraw-Hill.

[16]. Shamsuddin, K., et al., (2013). Correlates of depression, anxiety and stress among Malaysian university students. Asian J. Psychiatry http://dx.doi.org/10.1016/j.ajp.2013.01.014

[17]. Sobocki P, Lekander I, Borgstrom F, Strom O, Runeson B (2007). The economic burden of depression in Sweden from 1997 to 2005. Eur Psychiatry, 22(3): 146- 152.

[18]. Spielberger, CD and Sydeman, SJ (1994). State-trait anxiety inventory and state-trait anger expression inventory. In ME. Maruish (Ed.), The use of psychological tests for treatment planning and outcome assessment (pp. 292-321). Hillsdale, NJ: Erlbaum.

[19]. Spiessl H, Hubner-Liebermann B, Hajak G (2006). Depression, a widespread disease. Epidemiology, care situation, diagnosis, therapy and prevention]. Dtsch Med Wochenschr, 131(1-2): 35-40.

[20]. Stewart-Brown S, Evans J, Patterson J, Petersen S, Doll H, Balding J, Regis D (2000). The health of students in institutes of higher education: an important and neglected public health problem? J Public Health Med 22(4):492-499

[21]. Teh CK, Ngo CW, Zulkifli RA., Vellasamy R. and Suresh K (2015). Depression, anxiety and stress among undergraduate students: a cross sectional study. Open Journal of Epidemiology, 5, 260268.http://dx.doi.org/10.4236/ojepi.2015.54030

[22]. Tomoda A, Mori K, Kimura M, Takahashi T, Kitamura T (2000). One year prevalence and incidence of depression among first year university students in Japan: a preliminary study. PsychiatClin Neuros 54:583-588

[23]. Turner RJ, Lloyd DA (2004). Stress burden and the lifetime incidence of psychiatric disorder in young adults: racial and ethnic contrasts. Arch Gen Psychiatry; 61:481-8.

[24]. Vaez M, Kristenson M and Laflamme L (2004). Perceived quality of life and self-rated health among first-year University students. Social Indicators Research, 68, 221-234.

[25]. Wintre, M.G. and Yaffe, M. (2000). First-year students' adjustment to university life as a function of relationships with parents. Journal of Adolescent Research, 15, 9-37.

[26]. Wong WS, Cheung PT, Chan KC, Ma KM, Tang SW (2006). Web-based survey of depression, anxiety and stress in first-year tertiary education students in Hong Kong. Aus N Z J Psychiat 40(9):777-782 


\title{
Knowledge, Attitude and Acceptability of Premarital Genetic Services for Sickle Cell Disease among Undergraduates of a Nigerian Private Tertiary Institution
}

\author{
Article by Olufisayo. A Bademosi ${ }^{1}$, Titilayo Olaoye ${ }^{2}$, Saratu. O Ajike ${ }^{3}$ \\ ${ }^{1,2,3}$ Department of Public Health School of Public \& Allied Health, Babcock \\ University, Ilishan-Remo, Ogun state, Nigeria. \\ ${ }^{3}$ Email:suo2009@gmail.com
}

\begin{abstract}
In Nigeria annually, 150,000 children are born with sickle cell anemia. One way of preventing sickle cell disease is through premarital genetic counseling and screening. This study therefore assessed the knowledge, attitude and acceptability of premarital genetic services for sickle cell disease among Babcock University Undergraduates.

The study was descriptive and cross sectional in design. Three hundred and seventy seven respondents were randomly selected using multistage sampling technique. Data was collected using a validated semi-structured questionnaire that was self-administered with a CronbachAlpha test of 0.747. It was analyzed using the statistical package for social science (SPSS) version 21 to generate descriptive and inferential statistics.

The results showed that more than half 229 (60.7\%) of the respondents were females while 148 (39.3\%) of the respondents were males. Three hundred and fifteen of the respondents were between the age range of 16-20 years with the mean age of 18.99 and $S D \pm 0.107 .363$ (96.3\%) of respondents had heard of sickle cell diseasewhile, 229 (60.7\%) agreed that intending couples should attend premarital genetic services and thus showed positive attitude. Another 350 (92.8\%) of the respondents would undergo premarital genetic services if it is available. There is a significant difference between knowledge and acceptability of respondents towards premarital genetic services $(P=0.047)$

In conclusion, the respondents had a high level of knowledge and acceptability on premarital genetic services and sickle cell disease. All sectors should increase efforts in creating awareness about premarital genetic services and locations.
\end{abstract}

Keywords: Premarital, genetic services, Knowledge, Acceptability, Attitude, sickle cell anemia

\section{Introduction}

Screening before a marital union may be considered as a more important measure for primary prevention, than neonatal screening which serves as secondary or tertiary prevention (Tamhankar et al, 2009). This is especially true for intending couples. Healthy marriage is defined as "state of agreement and harmony between the marriage partners with regard to the healthy, psychological, sexual, social, and legislative aspects, aiming at making a sound family and begetting healthy, happy children.” Hereditary or contagious diseases can disturb this "happy life" leading to psychological, social and economic problems as well as medical complications with their reflection on the patient, family and society (Ministry of Health Portal, Kingdom of Saudi Arabia, 2014).

The commonest hereditary disease in Africa has been identified as sickle cell disease (WHO, 2011). In Nigeria, Sickle cell anemia remains a public health problem. Twenty-four percent of the population are carriers of the mutant gene and the prevalence of sickle-cell anaemia is about 20-30 per 1000 births (WHO, 2006).Sickle cell disease is a term used for a group of conditions in which the red blood cells have an abnormal type of haemoglobin called haemoglobin S (Anie, 2010). This disease occurs due to the inheritance of the mutant haemoglobin genes from both parents (Moronkola et al, 2007). Sickle-cell disease also has 
major psychological, social and economic implications for the affected child as well as the family (Anie, 2010).

Sickle cell disease can only be cured by bone marrow transplant also known as stem cell transplant. It is a very expensive treatment and involves replacing the affected bone marrow with bone marrow transplanted by someone without sickle cell disease. This is not feasible in low income countries (Owolabi et al, 2011). Therefore, for Africans and in particular Nigerians, an important and cost effective approach for controlling the disease is preventionand this depends upon the detection of carriers, genetic counseling, prenatal screening for fetal genotype in couples who are both carriers and newborn screening for sickle cell genotype (Owolabi et al, 2011).

Recent reports showed that Nigeria alongside India, and the Democratic Republic of the Congo [DRC] contributed 57\% of the global total of newborns with sickle cell anemia. The contributions of the two lattercountries have been projected to decrease by 2050, but the contribution of Nigeria has been projected to increase from the present 30\% to 35\% by 2050 (Piel, Hay, Gupta, Weatherall, \&Williams, 2013). This calls for the urgent introduction of premarital genetic services in Nigeria, to bring down the projected increase. Moreover, religious and cultural beliefs of people regarding the origin of sickle cell disease and its treatment are drawbacks. There is still a palpable lack of information about the disorder which, with the increasing prevalence, has encouraged the growth of myths, misinformation, inappropriate treatment, frustration and stigmatization (Diallo, \& Tchernia, 2007).

Tertiary institutions in Nigeria usually comprise mainly of youths who are unmarried and intend to get married and procreate in future. Many university students do not view sickle cell anaemia and genotype incompatibility as issues to be considered in making marital decisions and therefore might be willing to proceed with marriage in such circumstances (Alao\&Nwannadi, 2009). This study therefore sought to find out if undergraduates are knowledgeable, have a very positive attitude and high acceptability of these premarital genetic services available for the prevention of sickle cell disease. The information obtained from this study would encourage counsellors and programme planners to intensify awareness campaigns on premarital genetic services among Nigerian undergraduates (Moronkola \& Fadairo, 2009).

\section{Materials and methods}

The study was a cross-sectional survey utilizing a pre-tested questionnaire (Cronbach's alpha of 0.747) to collect information about the Knowledge, Attitude and Acceptability of Premarital Genetic Services for Sickle cell disease among Babcock University undergraduates. Informed consent was sought from all the volunteer participants. Four hundred participants between the ages 15-24 were selected from students living on campus using multistage sampling technique. Questionnaires constructed were served to the participants who were required to fill the four sections.

The sample size used was drawn from the total study population by using the Cochran formula (Cochran 1963) for determining minimum sample size. Where $n=Z^{2} p q / d^{2}$

Where, $\mathrm{n}=$ minimum sample size; $\mathrm{Z}=$ standard normal deviation set at 1.96; $\mathrm{p}=$ =estimated prevalence of sickle cell disease in Africa averagely 25\% i.e. 0.25 (WHO, 2006); q=1-p (1$0.25)=0.75 ; d=$ degree of accuracy desired $5 \%(0.05)$ Therefore $n=(1.96)^{2} \times 0.25(0.75) /$ (0.05). Hence $n=288.12$. The minimum sample size is approximated to 300 participants. An additional 100 questionnaires was added to the minimum sample size to ensure that there is no type 1 error and to accommodate "No response".

Of the 400 questionnaires distributed, only 377 questionnaires were retrieved. The statistical analysis was done using the SPSS version 21.0 statistical software packages. The data collected were subjected to descriptive and inferential statistics using the information obtained and were summarized and presented into tables and charts and Pearson's Chi square. Knowledge scores were computed using 1 for the correct answer and 0 for the wrong answers for each of the knowledge questions on an 11- point scale. For each questions, two answers 
were available; Yes and No. The maximum score obtainable was 11 while the minimum was 0 . An addition of the knowledge score was done by adding together individual knowledge scores. The scores were then classified into two categories by taking the mean of the highest and lowest scores and a value of 7 was gotten. This was used to classify respondents into high and low levels of knowledge. Scores between 0-5.5 are low and 5.6 to 11 are a high level of knowledge. Attitude scores were computed by awarding 1 mark for each correct answer to 8 statements which assessed respondents' attitudes to premarital genetic services on a 32 point scale. For each item, there were four responses: Strongly Agree, Agree, Disagree, and Strongly Disagree. A composite attitude score was compiled by adding together the individual attitude scores. The scores were then classified into two categories by taking the mean of the highest and lowest scores and a value of 18.6499 was obtained. This was used to classify into low, average and high levels of attitude. Scores from 9-16 were low attitude and scores from 17-21 as moderate attitude and 22-30 were regarded as high attitude.

\section{Ethical consideration}

Informed consent was gotten from participants and a brief introduction of the researcher and details of the research was explained. Participants were provided voluntary participation and were free to withdraw if and when they wanted. The information obtained from the participants was treated with utmost confidentiality and an ethical clearance from was gotten from Babcock University Health and Research Ethics Committee (BUHREC) before the commencement of the research.

\section{Results}

Table 1. Socio-demographic distribution of Respondents

\begin{tabular}{lll}
\hline Characteristics & $\begin{array}{l}\text { Frequency } \\
(\mathbf{n = 3 7 7 )}\end{array}$ & $\begin{array}{l}\text { Percentage } \\
(\mathbf{1 0 0 \% )}\end{array}$ \\
\cline { 2 - 3 } AGE & & \\
$<15$ & 6 & 1.6 \\
$16-20$ & 315 & 83.6 \\
$21-25$ & 48 & 12.7 \\
$26>$ & 9 & 2.4 \\
GENDER & & \\
Male & 148 & 39.3 \\
Female & 229 & 60.7 \\
RELIGION & & \\
Christianity & 325 & 86.2 \\
Islam & 47 & 12.5 \\
Others & 5 & 1.3 \\
\hline
\end{tabular}

As shown in table 4.1 below majority 315 (83.6\%) of the respondents are between the ages 16-20, while $6(1.6 \%)$ were between the 14-15 years of age with a mean age of 18.99 and S.D \pm 0.107 . Three hundred and twenty-five were Christians. Females were in the majority. 
Texila International Journal of Public Health

Volume 4, Issue 3, 2016

Table 2. Knowledge about Sickle Cell Disease and Premarital Genetic Services

\begin{tabular}{|c|c|c|c|}
\hline Variables & Categories & $\begin{array}{l}\text { Frequency } \\
(\mathrm{n}=377)\end{array}$ & $\begin{array}{l}\text { Percentage } \\
(100 \%)\end{array}$ \\
\hline \multirow{2}{*}{$\begin{array}{l}\text { Do you know about sickle } \\
\text { cell disease? }\end{array}$} & Yes & 363 & 96.3 \\
\hline & No & 14 & 3.7 \\
\hline \multirow{3}{*}{$\begin{array}{l}\text { How can sickle cell disease } \\
\text { be transmitted? }\end{array}$} & From inheriting two abnormal & 362 & 96.3 \\
\hline & eating poorly & 6 & 1.6 \\
\hline & $\begin{array}{l}\text { From not using protection during } \\
\text { sexual intercourse }\end{array}$ & 8 & 2.1 \\
\hline \multirow{2}{*}{$\begin{array}{l}\text { Do you know anyone with } \\
\text { sickle cell disease? }\end{array}$} & Yes & 260 & 69 \\
\hline & No & 45 & 11.9 \\
\hline \multirow{4}{*}{$\begin{array}{l}\text { What are the symptoms of } \\
\text { sickle cell disease? }\end{array}$} & Yellowing of eyes & 197 & 52.1 \\
\hline & Swollen hands and feet & 326 & 86.5 \\
\hline & Getting sick everyday & 124 & 32.8 \\
\hline & Swollen tummy & 304 & 80.7 \\
\hline \multirow{2}{*}{$\begin{array}{l}\text { Have you heard about } \\
\text { Genotype? }\end{array}$} & Yes & 360 & 95.5 \\
\hline & No & 17 & 4.5 \\
\hline \multirow{2}{*}{$\begin{array}{l}\text { Do you know your } \\
\text { genotype? }\end{array}$} & Yes & 332 & 88.1 \\
\hline & No & 45 & 11.9 \\
\hline At what age should one & 5-12 years & 210 & 55.7 \\
\hline \multirow{2}{*}{ know their genotype } & $13-20$ years & 147 & 39 \\
\hline & 21 and above & 20 & 3.1 \\
\hline \multirow{3}{*}{$\begin{array}{l}\text { Why should one know } \\
\text { their genotype? }\end{array}$} & For marriage & 321 & 85.2 \\
\hline & For blood transfusion & 257 & 68.2 \\
\hline & For general knowledge & 280 & 74.3 \\
\hline \multirow{2}{*}{$\begin{array}{l}\text { Have you heard about } \\
\text { premarital genetic services }\end{array}$} & Yes & 173 & 45.9 \\
\hline & No & 204 & 54.1 \\
\hline \multirow{3}{*}{$\begin{array}{l}\text { What are premarital } \\
\text { genetic services? }\end{array}$} & Services for intending couples & 159 & 91.9 \\
\hline & $\begin{array}{l}\text { Services done in a church betore } \\
\text { marriage Activities to find out } \\
\text { your health status }\end{array}$ & 4 & 2.3 \\
\hline & & 10 & 5.8 \\
\hline Do you know where the & Yes & 105 & 60.7 \\
\hline
\end{tabular}


What are the likely centres for premarital genetic services

Sources of information about sickle cell disease
Sickle cell centre/marriage counselling

Hospital 337

Church 18

Media Friends and peers Health 275 personnel Seminar/lecturesFamily 280

Sources of information about PGS

$\begin{array}{lll}\text { Media Friends and peers Health } & 162 & 43 \\ \text { personnel Seminar/Lectures } & 36 & 9.6 \\ \text { Family } & 49 & 13 \\ & 39 & 10.4 \\ & 39 & 10.4\end{array}$

As shown in Table 2, 363 (96.3\%) of respondents had heard of sickle cell disease and knew it was transmitted from inheriting two abnormal genes "S" from one's parents. Many, 260(69\%) of the respondents knew someone with sickle cell disease.The major source of information on sickle cell was the family, 312 (82.8\%). Three hundred and sixty of the respondents (95.5\%) had heard about genotype, but only 332 (88.1\%) knew their genotypes. Three hundred and twenty-one (85.2\%) indicated marriage as the reason for knowing one's genotype. One hundred and seventy-three (45.9\%) had heard about PGS, majorly from the media, 162 (43\%) but only 105 (60.7\%) knew where these services are rendered, while 337 (89.5\%) selected the hospital as a centre for PGSs.

Table 3. Relationship status and knowledge of partners' genotype characteristics

\begin{tabular}{llll}
\hline Variables & Categories & $\begin{array}{l}\text { Frequency } \\
\text { (n=162) }\end{array}$ & $\begin{array}{l}\text { Percentage } \\
\text { (\%) }\end{array}$ \\
\hline Are you in a relationship? & Yes & 162 & 43 \\
& No & 215 & 57 \\
How long have you been in a & $1-6$ months & 70 & 43.2 \\
relationship? & $7-12$ months & 30 & 18.5 \\
& $>1$ year & 62 & 38.3 \\
Do you know the genotype & Yes & 110 & 67.9 \\
of your partner? & No & 52 & 32.1 \\
$\begin{array}{l}\text { What are the symptoms of } \\
\text { sickle cell disease }\end{array}$ & $\begin{array}{l}\text { Yellowing of } \\
\text { eyes }\end{array}$ & 83.9 & 52.1 \\
& $\begin{array}{l}\text { Swollen hands } \\
\text { and feet }\end{array}$ & 140 & 86.5 \\
& $\begin{array}{l}\text { Getting sick } \\
\text { everyday }\end{array}$ & 53.1 & 32.8 \\
& Swollen tummy & 131 & 80.7 \\
\hline
\end{tabular}

According to Table 3 on relationship status, 162 (43\%) were in a relationship. Of those who were in a relationship, 70 (43.2\%) had been in the relationship for 1-6 months, while 31 (18.5\%) of the respondents had been in a relationship for 7-12 months. One hundred and ten (67.9\%) of the respondents knew the genotype of their partners. Of these, 103(94\%) in total could confidently mention the partner's genotype 
Texila International Journal of Public Health

Volume 4, Issue 3, 2016

The knowledge of respondents was generally high at $7.11(\mathrm{SD}=2.1010)$ on a scale of 11 .

More than half of the respondents, 251 (66.9 \%) indicated that lack of awareness may hinder them from participating in premarital services.

Table 4. Respondents attitude towards premarital genetic services (PGS)

\begin{tabular}{|c|c|c|c|c|}
\hline Attitude towards PGS & $\begin{array}{l}\text { Strongly } \\
\text { Agree }\end{array}$ & Agree & $\begin{array}{l}\text { Strongly } \\
\text { Disagree }\end{array}$ & Disagree \\
\hline $\begin{array}{l}\text { Irrespective of the genotype of my partner, I will go } \\
\text { ahead with my relationship because all that matters } \\
\text { is love. }\end{array}$ & 5.2 & 12.8 & 49.2 & 29.7 \\
\hline $\begin{array}{l}\text { My belief does not emphasize on premarital genetic } \\
\text { service so it's not important }\end{array}$ & 4.4 & 14.1 & 44.3 & 32.6 \\
\hline I am too young to be bothered about my genotype & 3.9 & 2.6 & 60.2 & 29.9 \\
\hline $\begin{array}{l}\text { Genotype or not, God is the one who determines } \\
\text { my partner }\end{array}$ & 28.6 & 32.3 & 17.2 & 18.5 \\
\hline $\begin{array}{l}\text { All would-be- couples should undergo premarital } \\
\text { genetic services. }\end{array}$ & 60.7 & 28.4 & 3.9 & 3.1 \\
\hline $\begin{array}{l}\text { Because I and my partner hardly fall sick, we are } \\
\text { healthy and do not need to undergo any tests }\end{array}$ & 3.6 & 6.0 & 57.3 & 29.4 \\
\hline $\begin{array}{l}\text { Because of my genotype, I am at risk of having } \\
\text { children with sickle cell disease }\end{array}$ & 9.9 & 21.1 & 40.1 & 24.2 \\
\hline $\begin{array}{l}\text { Sickle cell disease is not the worst genetic disease } \\
\text { so one can live with it. }\end{array}$ & 25.5 & 39.1 & 16.1 & 16.7 \\
\hline
\end{tabular}

According to table 4 below, about 50\% disagreed to the notion that love should be the sole reason for going into marriage. Also, 44.3\% did not believe religion should override the importance of PGS. 60.7\% strongly agreed that all intending couples undergo premarital genetic services. In addition, 57.3\% did not believe in disregarding genetic tests irrespective of good health.

Overall the attitude of the respondents was moderate $(\mathrm{SD}=3.422$; mean $=18.65)$ on a scale of 30 . 
Table 5. Factors influencing PGS and its acceptability

\begin{tabular}{|c|c|c|c|}
\hline Variables & Categories & Frequency $(\mathrm{n}=377)$ & Percentage (\%) \\
\hline $\begin{array}{l}\text { Would you undergo } \\
\text { premarital genetic } \\
\text { services if available? }\end{array}$ & $\begin{array}{l}\text { Yes } \\
\text { No }\end{array}$ & $\begin{array}{l}350 \\
27\end{array}$ & $\begin{array}{l}92.8 \\
7.2\end{array}$ \\
\hline $\begin{array}{l}\text { Would you want } \\
\text { premarital genetic } \\
\text { services to be made } \\
\text { compulsory }\end{array}$ & $\begin{array}{l}\text { Yes } \\
\text { No }\end{array}$ & \begin{tabular}{|l|}
320 \\
57
\end{tabular} & $\begin{array}{l}84.9 \\
15.1\end{array}$ \\
\hline $\begin{array}{l}\text { Reasons for } \\
\text { undergoing } \\
\text { Premarital genetic } \\
\text { counselling }\end{array}$ & $\begin{array}{l}\text { Personal belief } \\
\text { Encouragement from } \\
\text { my place of worship } \\
\text { Influence from my } \\
\text { friends and partner } \\
\text { If my family } \\
\text { encourages me to }\end{array}$ & $\begin{array}{l}307 \\
109 \\
130 \\
128\end{array}$ & $\begin{array}{l}81.5 \\
28.9 \\
\\
34.6 \\
33.9\end{array}$ \\
\hline $\begin{array}{l}\text { Benefits of accepting } \\
\text { premarital genetic } \\
\text { counselling }\end{array}$ & $\begin{array}{l}\text { Awareness of } \\
\text { genotype and making } \\
\text { right choices } \\
\text { Making everyone } \\
\text { happy } \\
\text { Prevention of disease } \\
\text { in unborn child }\end{array}$ & $\begin{array}{l}271 \\
66 \\
296\end{array}$ & $\begin{array}{l}71.9 \\
17.4 \\
78.6 \\
\end{array}$ \\
\hline $\begin{array}{l}\text { Barriers to } \\
\text { participating in PGS }\end{array}$ & $\begin{array}{l}\text { Not having genetic } \\
\text { disease trait } \\
\text { Not in a relationship } \\
\text { Busy university } \\
\text { schedule } \\
\text { Lack of awareness }\end{array}$ & $\begin{array}{l}138 \\
110 \\
121 \\
251\end{array}$ & $\begin{array}{l}36.7 \\
29.2 \\
32 \\
66.7\end{array}$ \\
\hline
\end{tabular}

As shown in Table 5 above, 350 (92.8\%) of respondents' revealed that they would undergo premarital genetic services if it was available and 320 (84.9\%) would want it to be made compulsory. Three hundred and thirteen (81.5\%) of the respondents will undergo PGS due to their personal beliefs while 111(28.9\%) would undergo if their place of worship encourages them to.

The following benefits were reported by the respondents for undergoing premarital genetic services, 302 (78.6\%) of the respondents indicated that it is to prevent their unborn children from having genetic disease, while $67(17.4 \%)$ of the respondents indicated it is to make everyone around them happy.

Table 6. Test of Relationship between knowledge of participants and acceptability of PGS

\begin{tabular}{llll}
\hline & Value & Df & sig (2 sided) \\
\hline Pearson's Chisquare & 40.995 & 4 & 0.000 \\
\hline
\end{tabular}

$\mathbf{H}_{\mathbf{0}}$ : there will be no significant difference between gender and knowledge of respondents on premarital genetic services for sickle cell disease

$\mathbf{H}_{1}$ : there will be a significant difference between gender and knowledge of respondents on premarital genetic services for sickle cell disease. 
Texila International Journal of Public Health

Volume 4, Issue 3, 2016

As shown in the table 5 above, at a value of $40.995, \mathrm{P}<0.05$, the null hypothesis is rejected which means that there is a significant difference between gender and knowledge. Females have a higher knowledge about premarital genetic services and sickle cell disease than the males

\section{Discussion}

\section{Knowledge about sickle cell disease and premarital genetic services?}

This research revealed that almost half of the respondents had heard about premarital genetic services (PGS) and knew about sickle cell disease. These findings are similar with studiesby Oludare et al (2013), where $80 \%$ of youths had good knowledge about sickle cell disease and premarital counselling and Olubiyi et al (2013) where 97.8\% of the participants had high knowledge about sickle cell disease. This is at variance with a study done in Jeddah where female students of Abdul-Aziz University had low level of knowledge about premarital genetic services (Ibrahim et al, 2011). This study was among unmarried females which could account for poor knowledge since they were not considering marriage and would not have sought information at the time.

Compared to the study by Olubiyi et al (2013) where about $57 \%$ of the respondents could define premarital genetic services correctly, most of the respondents could correctly state what PGS is.

\section{Attitude of respondents towards premarital genetic services}

The attitude of the respondents was fair. Very few (18\%) agreed to the notion that "love" could save a relationship threatened illness. This is contrary to the findings of Alao et al (2009) where $43 \%$ of the respondents will continue with their relationship irrespective of genetic incompatibility.

Based on the study, religious acceptability of premarital genetic services will encourage individuals to see its' importance. This is in line with the study by Nnaji et al (2013) in Nnewi where different religious institutions (Pentecostal and orthodox) mainly influenced an individual's decision to undergo premarital genetic services but in variance with Omuemu et al (2013) study in Benin where religious beliefs did notinfluence their decisions for premarital genetic services. The latter studies' findings may be as a result of the religious nature of the tertiary institutions used for this study.

\section{Relationship status and knowledge of partners' genotype}

Majority of the respondents in the study knew their genotype. Similar findings by Olubiyi et al in Ekiti State University showed a high percentage (90.3\%) of the respondents knew their genotypes. However, Alao et al (2010) recorded a lower percentage (41.2\%) who knew their partners' genotype. There are strong differences regarding knowledge of partners' genotype in different populations.

\section{Willingness to accept premarital genetic services and factors influencing acceptance}

This research study reveals that most of the respondents would undergo premarital genetic services if available. This aligns withother studies. For instance $80 \%$ of respondents, in study by Isah et al (2016) were willing to undergo premarital genetic counselling with their partners. A Similar study by Oyedele, et al, (2015) carried out in Plateau found that the majority of the respondents (77.3\%) accepted to go for premarital genotype screening. Another study by Omuemu et al amongst university undergraduates in Benin City, Edo state found that the level of acceptability of genetic screening for sickle cell disease by participants was high (96.6\%). There is therefore general acceptance of PGS and a need to include services of this nature in youth health services.

The findings of this study revealed that majority of the respondents (66.9 percent) indicated that lack of awareness may hinder them from participating in premarital genetic 
service, almost half of the respondents indicated not having a genetic trait as another factor. Busy university schedule and not being in a relationship took a slightly lower percentage. However, the two topmost reasons for not participating in PGS were "supposed healthy look" and fear of losing partners in the study by Olubiyi et al (2013). This suggests that public enlightenment on premarital genetic services is still needed to heighten people's awareness about where PGS can be located.

\section{Relationship between the knowledge and acceptability of the respondents towards premarital genetic services}

As statistically proven in the study there is a significant difference between knowledge and acceptability of respondents towards PGS. This is in line with the study by Oyedele et al (2015) in Jos where a significant difference existed between awareness and acceptability of premarital genetic services at a calculated chi square of 22.7, the null hypothesis was rejected. This may be because having a high knowledge about sickle cell disease and how it can be prevented might have increased the individuals' acceptance of the services.

\section{Conclusion and implications for public health practice}

In this study, very few respondents had heard about premarital genetic services as compared with knowledge about sickle cell disease. It confirms the gap existing between classroom knowledge and access to services. Premarital counseling is one of the most important strategies for prevention of genetic disorders, congenital anomalies, and several medical psychosocial marital problemsThus, premarital counseling service should be a very strong health promotion tool for preventing diseases and increasing the quality of life. School health services have a role to playin bridging the gap between knowledge and practice especially as some relationships which begin in the university end up in marriage unions. This can safeguard the health of future generations.

\section{Recommendations}

Comprehensive sexuality education helps youths assume responsibility for life-long sexual health by providing medically accurate information and enhancing decision-making skills at a crucial developmental stage. Thus, PGS should be incorporated intoschools' curriculum involving all age and department categories with special focus on students. Also Youth Friendly services should incorporate services of this kind into their programmes.

\section{References}

[1]. Alao, O.O., Araoye, M., \& Ojabo, C. (2009). Knowledge of sickle cell disease and haemoglobin electrophoresis: a survey of students of a tertiary institution. Nigerian Journal of Medicine, 18(3), 3269. Retrieved from http://www.ncbi.nlm.nih.gov/pubmed/20120655

[2]. Al-Khaldi, Y. M., Al-Sharif, A. I., Sadiq, A. A., \& Ziady, H. H. (2002). Attitudes to premarital counseling among students of Abha Health Sciences College. Saudi Medical Journal, (8), 986-990. Retrieved

from https://www.researchgate.net/publication/11156130_Attitudes_to_premarital_counseling_among_stude nts_of_Abha_Health_Sciences_College

[3]. Anie, K. A., Egunjobi, F. E., Akinyanju, O. O. (2010). Psychosocial impact of sickle cell disorder: Perspectives from a Nigerian setting. Globalization and Health, 6(2). DOI: 10.1186/17448603-6-2

[4]. Diallo, D., \& Tchernia, G. (2002) Sickle cell disease in Africa. Current Opinion in Hematology, 9, 111-116. Retrieved from http://www.ncbi.nlm.nih.gov/pubmed/11844993

[5]. Ibrahim, N.K.R., Al-Bar, H., Al-Fakeeh, A., Al-Ahmadi, J., Qadi, M., Al-Bar A., \& Milaat, W. (2011). An educational programme about pre-marital screening for unmarried female students in King Abdul-Aziz University, Jeddah. Journal of Infection and Public Health, 4(1), 30-40. DOI: http://dx.doi.org/10.1016/j.jiph.2010.11.001 
Texila International Journal of Public Health

Volume 4, Issue 3, 2016

[6]. Isah, B. A., Musa, Y., Mohammed, U. K, Ibrahim, M. T. O., Awosan, K. J.,\& Yunusa, E. U.(2016). Knowledge and Attitude Regarding Premarital Screening for Sickle Cell Disease among Students of State School of Nursing, Sokoto. Annals of Internal Medicine, 2(3), 29-34. DOI: 10.21276/aimdr.2016.2.3.9

[7]. Ministry of Health Portal Kingdom of Saudi Arabia. (2014). Overview of Premarital Screening. Retrieved from http://www.moh.gov.sa/en/HealthAwareness/Beforemarriage/Pages/default.aspx

[8]. Moronkola, O. A., \& Fadairo, R. A. (2007). University students in Nigeria: Knowledge and attitude toward sickle cell disease, and genetic counseling before marriage. International Quarterly of Community Health Education, 26(1), 85-93. DOI: 10.2190/JN25-4353-75PK-3733

[9]. Nnaji, G. A., Ezeagwuna, D. A., Nnaji, I. J. F., Osakwe, J. A. (2013). Prevalence and Pattern of Sickle Cell Disease in Premarital Couples in South Eastern Nigeria. Nigerian Journal of Clinical Practice, 16(3), 309-314.Doi: 10.4103/1119-3077.113452.

[10]. Olubiyi, S. K., Umar, J. N., Ajiboye, O., Olubiyi, V. M., Abioye, T. A. S. (2013). Knowledge and attitude of undergraduates of Ekiti State University towards sickle cell disease and genetic counselling before marriage Sky Journal of Medicine and Medical Sciences 1(7): 29 - 35. Retrieved from http://www.skyjournals.org/sjmms/pdf/2013pdf/Nov/Olubiyi\%20et\%20al\%20pdf.pdf

[11]. Oludare, G.O., \& Ogili, M. C. (2013). Knowledge, Attitude and Practice of Premarital Counseling for Sickle Cell Disease among Youth in Yaba, Nigeria. African Journal of Reproductive Health, 17(4): 175 - 182. Retrieved from http://www.bioline.org.br/pdf?rh13067

[12]. Omuemu, V. O., Obarisiagbon, O. E.,\& Ogboghodo, E. O.(2013) Awareness and acceptability of premarital screening of sickle cell disease among undergraduate students of the University of Benin, Benin City, Edo State. Journal of Medicine and Biomedical Research; 12 (1), 91 - 104. Retrieved from http://www.ajol.info/index.php/jmbr/article/view/91817

[13]. Oyedele, E. A, Emmanuel, A., Gaji, L. D., Ahure, D. E. (2015). Awareness and acceptance of premarital genotype Screening among youths in a Nigerian community. International Journal of Medical and Health Research, 1(1), 17-21. Retrieved from

http://irepos.unijos.edu.ng/jspui/bitstream/123456789/992/1/1-1-30.pdf

[14]. Owolabi, R. S, Alabi, P., Olusoji, D., Ajayi, S., Otu, T., \& Ogundiran, A. (2011). Knowledge and attitude of secondary school students in Federal Capital Territory (FCT), Abuja, Nigeria towards sickle cell disease. Nigerian Journal of Medicine, 20(4), 479-485. Retrieved from http://www.ncbi.nlm.nih.gov/pubmed/22288328

[15]. Piel, F. B., Hay, S. I., Gupta, S., Weatherall, D. J., \&Williams, T. N. (2013) Global Burden of Sickle Cell Anaemia in Children under Five, 2010-2050: Modelling Based on Demographics, Excess Mortality, and Interventions. Retrieved from

http://journals.plos.org/plosmedicine/article?id=10.1371/journal.pmed.1001484

[16]. Tamhankar, P. M., Agarwal, S., Arya, V., Kumar, R., Gupta, U. R., \& Agarwal, S. S. (2009). Prevention of homozygous beta b-thalassemia by premarital screening and prenatal diagnosis in India. Prenatal Diagnosis, 29(1), 83-8.doi: 10.1002/pd.2176.

[17]. World Health Organization. (2006) Sickle-cell anaemia: Report by the Secretariat. Provisional agenda item 11.4 for the Fifty- Ninth World Health Assembly held on 26th April. Geneva. WHO. A59/9: 1 - 5. Retrieved from http://apps.who.int/gb/ebwha/pdf_files/WHA59-REC3/WHA59_REC3en.pdf

[18]. World Health Organisation. (2011). The Brazzaville declaration on Non-communicable diseases prevention and control in the WHO African region. Retrieved from

http://www.who.int/nmh/events/2011/ncds_brazzaville_declaration.pdf 


\title{
Evaluation of Prevention of Mother to Child Transmission of Human Immunodeficiency Virus Program (Option B+), Kadoma City, Zimbabwe, 2016
}

\author{
Article by Pamela Nyaradzai Magande ${ }^{1,}$ Notion Gombe ${ }^{1,}$ Donewell Bangure ${ }^{1}$, Mungati \\ More $^{1,}$ Tshimanga Mufuta ${ }^{1}$, Daniel Chirundu ${ }^{2}$ \\ ${ }^{1}$ Department of Community Medicine, University of Zimbabwe \\ Email:pmagande@gmail.com \\ gombent@yahoo.com \\ bangured@yahoo.com \\ mungatim@yahoo.com \\ tshimangamufuta@gmail.com \\ ${ }^{2}$ Kadoma City Health Department \\ Email:dchirundu@me.com
}

\begin{abstract}
Background: In 2013, Zimbabwe adopted Option B+, lifelong anti-retroviral therapy (ART) for all pregnant and breastfeeding HIV positive women and Nevirapine prophylaxis for their infants as a PMTCT method. Kadoma city started implementing the same in 2014. An evaluation was done to assess progress and determine reasons for loss of follow-up to advice and improve the program.

Methods: A process-outcome program evaluation using a logical framework was conducted. Pretested interviewer administered questionnaires, checklists and monthly reports were used for data collection. Epi Info 7 was used to calculate means and frequencies. Microsoft-Excel 2013 was used to consolidate monthly reports.

Results: Thirty health workers and 43 Option $B+$ clients were recruited. Although resources were limited, all the 324 women who tested positive in 2014 and 2015 received ART. CD4+ monitoring increased from 54\% in 2014 to 65\% in 2015. All the 240 exposed infants identified within 72 hours received Nevirapine prophylaxis in 2014 and 2015. HIV positivity at six weeks in infants decreased from 4\% in 2014 to 2\% in 2015. Reasons given by health workers for loss to follow-up were: clients' limited understanding (37\%), poor tracking mechanisms (23\%), mobility of clients (20\%), religious beliefs (17\%) and side effects (3\%). Clients' involvement in community support groups was poor (3\%).

Conclusions: Despite limited resources, there was an improvement in Option B+ services. Reasons for loss to follow-up include poor tracking mechanisms, clients' mobility, religious beliefs and side effects. Clients have been referred to community support groups and retention has improved.
\end{abstract}

Keywords: PMTCT, anti-retroviral therapy, Option B+, Kadoma, Zimbabwe Word count: 244

\section{Introduction}

The World Health Organization estimates 3.2 million children are living with Human Immuno-deficiency Virus (HIV) worldwide [1]. Ninety-one percent of these are in SubSaharan Africa [2]. In Zimbabwe, there are an estimated 144,575 children under the age of 14years living with HIV [3]. Mother to child transmission of HIV accounts for $90 \%$ of the HIV infections among children in Zimbabwe [4]. Therefore the need for effective Prevention of Mother to Child Transmission (PMTCT) of HIV cannot be overemphasized.

Zimbabwe has shown commitment to PMTCT since 1999. The initial pilot project has become a fully-fledged national program [4]. In that pilot, single dose Nevirapine was being used for PMTCT. In 2010, Zimbabwe adopted Option A as the national PMTCT regimen. 
This includes distinct treatment and prophylaxis components for antiretroviral therapy (ART) during pregnancy and breastfeeding [5]. In 2011, Zimbabwe was named one of 22 priority countries in the Global Plan for elimination of mother-to-child transmission of HIV [6]. In 2013, Option B+ (lifelong ART for pregnant and breastfeeding HIV positive women) was adopted [7, 8]. Use of the Option $\mathrm{B}+$ is aimed at reducing mother to child transmission of HIV to less than 5\% [9]. To achieve this, at least $90 \%$ of the mothers should be retained in care.

Kadoma, Zimbabwe started implementing Option B+ in 2014 to reduce the number of new HIV infections among children by $90 \%$ and to reduce the number of AIDS-related maternal deaths by $50 \%$. Pregnant and breastfeeding women who test HIV positive are initiated on lifelong ART. Their infants receive Nevirapine and Cotrimoxazole prophylaxis. These children are tested for HIV and initiated on ART if they are positive. This is guided by the national guidelines [7]. Since the introduction of Option B+ in 2014, there had not been any evaluation documented or otherwise to assess program performance. At the same time, the target of retaining at least $90 \%$ of the clients had not been met since program inception. We evaluated the program and identified the reasons for loss to follow up to advise and improve program implementation.

\section{Methods}

A program evaluation using the logical framework for process-outcome was conducted in Kadoma City, Zimbabwe. (Table 1). The four health centers under Kadoma City Council that provide PMTCT services were included in the study. All the 30 health workers who provide PMTCT services were interviewed. Using StatCalc and the study by Tenthani et.al. (2014)in which $17 \%$ of the clients appeared lost to follow-up at 6 months, at $95 \%$ confidence level, given that the number of clients registered in care at the time of the study was 189, the calculated sample size for the clients is 42 [10]. Clients were systematically sampled from the appointment registers. Interviewer administered questionnaires derived from the log-frame were used to subjectively assess the inputs and processes being carried out under Option B+. The questionnaires were translated into the local language and pretested at Kadoma General Hospital. Checklists were used to objectively assess the availability of inputs. Data were captured from the questionnaires and analyzed using Epi Info $7^{\mathrm{TM}}$ (CDC, 2012). Before analyzing, frequencies were run for each variable to assess for missing variables. Using the questionnaires, the missing information was added into Epi Info 7. Frequencies and means were calculated using this software. Monthly reports were consolidated and analyzed to assess outputs and outcomes using Microsoft Excel 2013. Written informed consent was obtained from all participants for both participation and publication. Permission and ethical approval was obtained from the Health Studies Office.

\section{Results}

\section{Demographic characteristics}

Thirty health workers were recruited in the study. Of these, 83 were female and $97 \%$ were nurses. The median age was 39.5 years $\left(\mathrm{Q}_{1}=35 ; \mathrm{Q}_{3}=48.5\right)$ and the median time in post was 5years $\left(\mathrm{Q}_{1}=1.5 ; \mathrm{Q}_{3}=13.5\right)$. (Table 2).

\section{Inputs for Option B+ in Kadoma city, 2016}

There were three months stocks of HIV test kits, adult medicines. Each of the four sites had a working cell phone and landline for communication. They also had functional laptops for data capturing. However, there were two months supplies of paediatric ART medicines and Cotrimoxazole was out of stock. Only two of the clinics had CD4+ machines. Twentynine nurses and one primary care counsellor were providing services against a staff establishment of 36 and four respectively. (Table 3) 


\section{Processes and outputs of the PMTCT (Option B+) program in Kadoma city, 2014-2015}

In 2014, all the 2,846 women who presented to the various entry points eligible for HIV testing were offered, counselled and tested. In the antenatal clinics, of the 1,210 tests performed, 78\% were first time tests. Thirteen percent (157) of the clients tested HIV positive in ANC, only 8\% (96) were initiated on ART. In labour and delivery, of the 58 women who were eligible for HIV tests, $10 \%$ (6) were positive and 5\% (3) were initiated on ART. In postnatal clinics, of the 223 women who were tested, 6\% (13) were positive but the number of women initiated on ART is $16 \%$ (36) of those tested.

In 2015, of the 2,179 tests performed under Option B+, 76\% were first time tests. Of these, $6 \%$ (131) tested positive and the same 6\% (131) were initiated on ART. In labour and delivery, of the 96 women who were eligible for HIV tests, 6\% (6) were positive and 6\% (6) were initiated on ART. In post-natal clinics, of the 571 women who were tested, 2\% (11) and the same were initiated on ART. ART was being initiated regardless of the presence or absence of initial CD4+ counts and the levels of the same. (Figure 1).

All the 240 exposed infants who were identified within 72hour received Nevirapine prophylaxis in 2014 and 2015. Amongst those who were identified after 73 hours, two (7\%) and nine (17\%) did not receive Nevirapine prophylaxis in 2014 and 2015 respectively. (Figure 2)

Of the 152 infants tested in 2014, 96(63\%) received their results. In 2015, 246(72\%) of 338 infants received their results. All the six infants (4\%) who tested DNA PCR positive in 2014 were initiated ART. The same was done for all five infants (2\%) who tested positive in 2015. (Figure 2)

CD4+ count is being used to monitor clients on treatment. This is offered at baseline and every six months. Ninety-five (54\%) of the 176 clients who were eligible for CD4+ testing received the test in 2014. In 2015, of the 263 clients who were eligible for CD4+ testing, $170(65 \%)$ managed to get the test.

\section{Outcomes of the PMTCT (Option B+) program in Kadoma city, 2014-2015}

There were no recorded deaths among women who had been enrolled under the PMTCT (Option $\mathrm{B}+$ ) program. HIV positivity among infants decreased from 4\% in 2014 to $2 \%$ in 2015.

\section{Reasons for loss to follow-up in Kadoma city, 2016}

Limited understanding on the part of clients (37\%), poor tracking mechanisms (23\%), mobility of clients (20\%), religious beliefs (17\%) and side effects (3\%) were given as reasons for loss to follow-up by health workers in Kadoma City. Twelve clients admitted to have faced problems since initiation of treatment. Of these nine cited side effects while three cited marital problems. Only $3 \%$ of the clients were in community support groups.

\section{Discussion}

The reasons for loss to follow-up were clients' limited understanding, religious beliefs and side effects among others. This is consistent with Tweya (2014) who reported similar results in Malawi [11]. In order to retain clients in care, interventions should aim at addressing the problems that the clients raise. One way of doing do is by allowing people who have gone through the same difficulties to advise those who are new to the program. This is where community support groups come in. In this study, only $3 \%$ of the clients were in support groups. Tenthani et.al. (2014) and Kalembo et.al. (2012) concluded that interventions such as community or family-based models of care could improve retention in care and indirectly effectiveness of Option $\mathrm{B}+[10,12]$. Applying the same in Kadoma could improve retention of clients.

In Kadoma there were fewer health workers, $\mathrm{CD}+$ machines and paediatric medicines than required for the provision of PMTCT services. It could have come about as a result of the 
government directive to freeze all post and not hire new employees. While it is expected given the current economic conditions, it could result in health worker burnt-out compromising the quality of services being provided. It is possible that the stock-out of paediatric Cotrimoxazole could have come about because the 'overworked' health workers may have forgotten to order the medicines.

As a result of the shortage of $\mathrm{CD}+$ machines, not all the clients who needed the service managed to get it. Trying to cater for all the clients can result in frequent breakdowns of the machines and it becomes a vicious cycle. This is consistent with an evaluation by NuwagabaBiribonwoha et.al. (2007) who also reported shortages of staff and supplies in Uganda [13]. According to Gallant et.al (2011) the effectiveness of patient management is affected by clinic staffing levels and available resources [14]. There is therefore need to advocate for more employees to meet staffing requirements and engage all stakeholders to source for more equipment.

Not all the women who needed ART were initiated in 2014. This could be explained by the fact that the program was still starting and therefore the performance not yet optimal. The transition from one set of guidelines to another could have resulted in women being missed with some health workers still using the old system. The health workers were being given onjob training and this process takes time. This is supported by the fact that when we come to 2015, all the women who needed ART were initiated signalling program maturity. While onjob training is effective and cheap there is need to sensitise all health workers on new guidelines so that a new program can easily take off. This can easily be done by conducting meetings to update all the health workers and displaying new guidelines on charts in the clinics.

The pregnant and breastfeeding women were initiated on ART regardless of absence or level of CD4+ counts. This practice is in line with the 2013 Zimbabwean and World Health Organisation treatment guidelines for HIV management [7, 8]. It allows pregnant and breastfeeding women to be expedited into care even in resource limited settings such as ours.

According to the national treatment guidelines all HIV exposed infants should be initiated on Nevirapine prophylaxis [8]. Although a small percentage of infants was missed in Kadoma, program performance was better than in the Oromia region in Ethiopia. Balcha et.al. (2011) reported that in this region, 71\% babies born to HIV-positive mothers did not access prophylactic medicine [15].

It was however difficult to assess HIV positivity beyond six weeks of age since the monthly reports were limited to six weeks after delivery. No further analysis beyond this age was possible for the infants. There is need to expedite the use of data collection tools that track the mother-baby pairs beyond six weeks. Further study to assess HIV positivity in children beyond six weeks would shed more light regarding the success of Option B+.

\section{Conclusion}

In Kadoma, the PMTCT (Option B+) program was being carried out following the national guidelines. The program gradually improved over time and in 2015, there was good program performance in spite of limited resources.The reasons for loss to follow-up include clients' limited understanding, poor tracking mechanisms, and mobility of clients, religious beliefs, side effects and marital problems. Clients were referred to community support groups and retention has improved.

\section{Acknowledgements}

We are grateful to Kadoma City Council for their support during the study. We are also grateful to the health workers in Kadoma for their day to day hard work and their cooperation during the conduct of this study. The authors are also grateful to the Zimbabwe MPH-FETP program and the Centers for Disease Control and Prevention (CDC) Zimbabwe for funding and technical assistance. 


\section{References}

[1]. WHO, HIV and AIDS, Treatment of children living with HIV, http://www.who.int/hiv/topics/paediatric/en/ Accessed 29 September 2015

[2]. Averting HIV and AIDS, Children, HIV and AIDS, http://www.avert.org/children-and-hivaids.htm, Accessed 29 September 2015

[3]. Zimbabwe National Statistics Agency (ZIMSTAT) and ICF International. 2012. Zimbabwe Demographic and Health Survey 2010-11. Calverton, Maryland: ZIMSTAT and ICF International Inc.

[4]. Ministry of Health and Child Care, Report of Mid-Term Review of the National eMTCT Strategic Plan 2011 - 15, National AIDS and Tuberculosis Unit,August - September 2013

[5]. Ministry of Health and Child Care, Zimbabwe. An Operational Plan for the Nationwide Transition to Option B+ in Zimbabwe: September 2013-November 2014. Available at:

http://www.nac.org.zw/sites/default/files/MoHCC_OpPlan_081113.pdf. Accessed 29 September 2015

[6]. Joint United Nations Programme on HIV/AIDS. Global Plan towards the Elimination of New HIV Infections among Children by 2015 and Keeping Their Mothers Alive. Geneva, Switzerland: UNAIDS; 2011.

[7]. World Health Organization. Consolidated Guidelines on the Use of AntiretroviralDrugs for Treating and Preventing HIV Infection: Recommendations for a Public Health Approach. Geneva, Switzerland: WHO Department of HIV/AIDS; 2013.

[8]. Ministry of Health and Child Care, Guidelines for Antiretroviral Therapy for the Prevention and Treatment of HIV in Zimbabwe, 2013,

[9]. Recommendations for use of antiretroviral drugs in pregnant HIV-1 infected women for maternal health and interventions to reduce perinatal HIV-1 transmission in the United States. Washington: US Public Health Service Task Force; 2005.https://aidsinfo.nih.gov/contentfiles/perinatalgl.pdf Accessed 29 September 2015

[10]. Tenthani L, Haas AD, Tweya H, Jahn A, van Oosterhout JJ, Chimbwandira F, et al. Retention in care under universal antiretroviral therapy for HIV-infected pregnant and breastfeeding women ('Option B+') in Malawi, AIDS, 2014 Feb 20;28(4):589-98.

[11]. Tweya H, (2014). Loss to follow-up among women in Option B+ PMTCT programme in Lilongwe, Malawi: Understanding outcomes and reasons, presentation at International AIDS Society.

[12]. Kalembo FW, Zgambo M, Loss to Followup: A Major Challenge to Successful Implementation of Prevention of Mother-to-Child Transmission of HIV-1 Programs in Sub-Saharan Africa, ISRN AIDS, 2012, 589817, 10

[13]. Nuwagaba-Biribonwoha H, Mayon-White RT, Okong P, Carpenter LM, Challenges faced by health workers in implementing the prevention of mother-to-child HIV transmission (PMTCT) programme in Uganda, Journal of Public Health, Vol. 29, No. 3, pp. 269-274

[14]. Gallant J, Adimora A, Carmichael J, Horberg M, Kitahata M, Quinlivan E, et.al.Essential Components of Effective HIV Care: A Policy Paper of the HIV Medicine Association of the Infectious Diseases Society of America and the Ryan White Medical Providers Coalition, 2011,Oxford University Press,

[15]. Balcha TT, Lecerof SS, Jeppsson AR, Strategic Challenges of PMTCT Program Implementation in Ethiopia, J IntAssoc Physicians AIDS Care (Chic), 2011, 10(3):187-92. 
Texila International Journal of Public Health

Volume 4, Issue 3, 2016

\section{Tables}

Table 1. Logical Framework (adapted from WHO HIV Consolidated Strategic Information guide)

\begin{tabular}{|c|c|c|c|c|}
\hline Inputs & Processes & Outputs & Outcomes & Impacts \\
\hline $\begin{array}{l}\text { Human Resources } \\
\text { Medicines } \\
\text { Consumables } \\
\text {-gloves } \\
\text {-delivery packs } \\
\text {-prophylaxis } \\
\text { medication } \\
\text { Communication } \\
\text { Vehicles and } \\
\text { transport } \\
\text { Diagnostic aids-e.g. } \\
\text { test kits } \\
\text { Stationery } \\
\text { Space and } \\
\text { infrastructure }\end{array}$ & $\begin{array}{l}\text { Health workers } \\
\text { training on Option } \\
\text { B+ } \\
\text { Community } \\
\text { mobilisation and } \\
\text { sensitization } \\
\text { Health education to } \\
\text { pregnant women, } \\
\text { new mothers and } \\
\text { their partners } \\
\text { Counselling of } \\
\text { pregnant women, } \\
\text { new mothers and } \\
\text { their partners } \\
\text { Initiating eligible } \\
\text { clients on ART }\end{array}$ & $\begin{array}{l}\text { Number of health } \\
\text { workers trained on } \\
\text { Option B+ } \\
\text { Number of } \\
\text { pregnant women } \\
\text { and their partners } \\
\text { counselled and } \\
\text { tested for HIV } \\
\text { Number of HIV } \\
\text { positive pregnant } \\
\text { women, new } \\
\text { mothers and infants } \\
\text { initiated on ART }\end{array}$ & $\begin{array}{l}\text { \% staff trained in } \\
\text { Option B+ } \\
\% \text { pregnant } \\
\text { women and new } \\
\text { mothers tested } \\
\text { for HIV } \\
\% \text { pregnant HIV } \\
\text { positive women } \\
\text { and new mothers } \\
\text { initiated on ART } \\
\% \text { pregnant HIV } \\
\text { positive women } \\
\text { and new mothers } \\
\text { retained in care } \\
\text { at } 6 \text { months } \\
\% \text { HIV exposed } \\
\text { infants identified } \\
\text { within } 72 h o u r s \\
\% \text { HIV positive } \\
\text { infants initiated } \\
\text { on ART }\end{array}$ & $\begin{array}{l}\text { Reduction of } \\
\text { HIV } \\
\text { transmission to } \\
\text { children to 5\% } \\
\text { Reduction of } \\
\text { maternal } \\
\text { mortality by } \\
50 \%\end{array}$ \\
\hline
\end{tabular}

Table 2. Demographic Characteristics of Health Workers in Option B+ in Kadoma, 2016

\begin{tabular}{ll}
\hline Variable & $\mathrm{n}(\%)$ \\
\hline Sex & $25(83)$ \\
Female & $5(17)$ \\
Male & \\
Designation & $14(47)$ \\
Midwife & $12(40)$ \\
Registered General Nurse & $3(10)$ \\
Sister In-Charge & $1(3)$ \\
Primary Care Counsellor & $39.5(35 ; 48.5)$ \\
Median age in years $\left(\mathrm{Q}_{1} ; \mathrm{Q}_{3}\right)$ & $5(1.5 ; 13.5)$ \\
Median years in post $\left(\mathrm{Q}_{1} ; \mathrm{Q}_{3}\right)$ & \\
\hline
\end{tabular}


Table 3. Required Inputs for Option B+ in Kadoma City, 2016

\begin{tabular}{|c|c|c|}
\hline & Available & Target \\
\hline \multicolumn{3}{|l|}{ Human Resources } \\
\hline Nurses & 29 & 36 \\
\hline Primary care counsellor & 1 & 4 \\
\hline \multicolumn{3}{|l|}{ Medicines } \\
\hline Adult & -Three months’ supply & -Three months’ supply \\
\hline \multirow[t]{2}{*}{ Paediatric } & -Two months' supply- & -Three months' supply- \\
\hline & $\begin{array}{l}\text { Cotrimoxazole out of } \\
\text { stock }\end{array}$ & Three months' supply \\
\hline \multicolumn{3}{|l|}{ Diagnostic aids } \\
\hline Test kits & -Three months’ supply & -Three months’ supply \\
\hline CD4+ machines & 2 & One at each site(5) \\
\hline Viral load machines & 0 & 1 \\
\hline \multicolumn{3}{|l|}{ Communication } \\
\hline Landline & One at each site & One at each site \\
\hline Cellular phones & One at each site & One at each site \\
\hline Air time & Inadequate & Available on demand \\
\hline Laptop & One at each site & One at each site \\
\hline Internet connectivity & None & Available at all centres \\
\hline
\end{tabular}

\section{Figures}

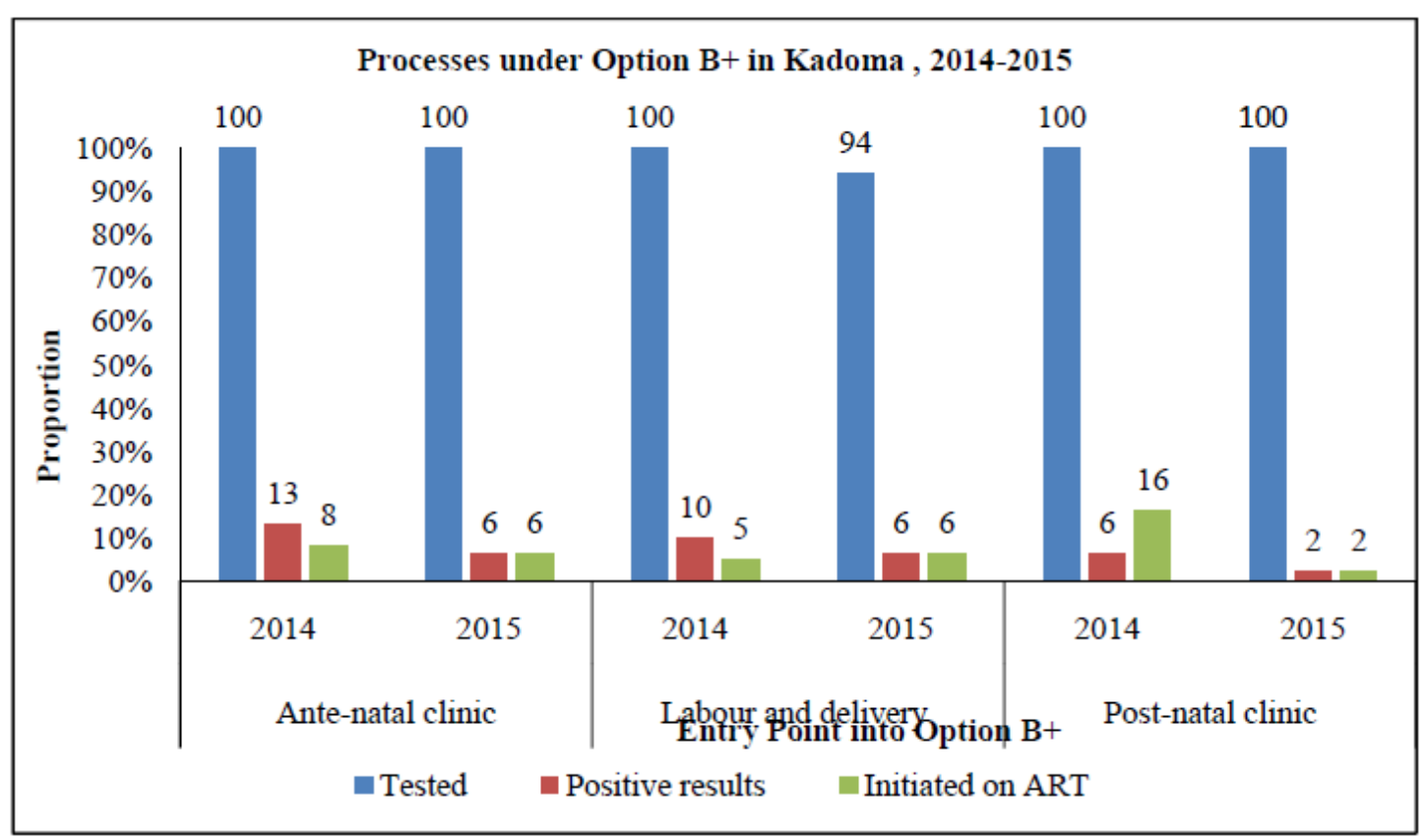

Figure 1. Processes under Option B+ in Kadoma City, 2014-2015 
Texila International Journal of Public Health

Volume 4, Issue 3, 2016

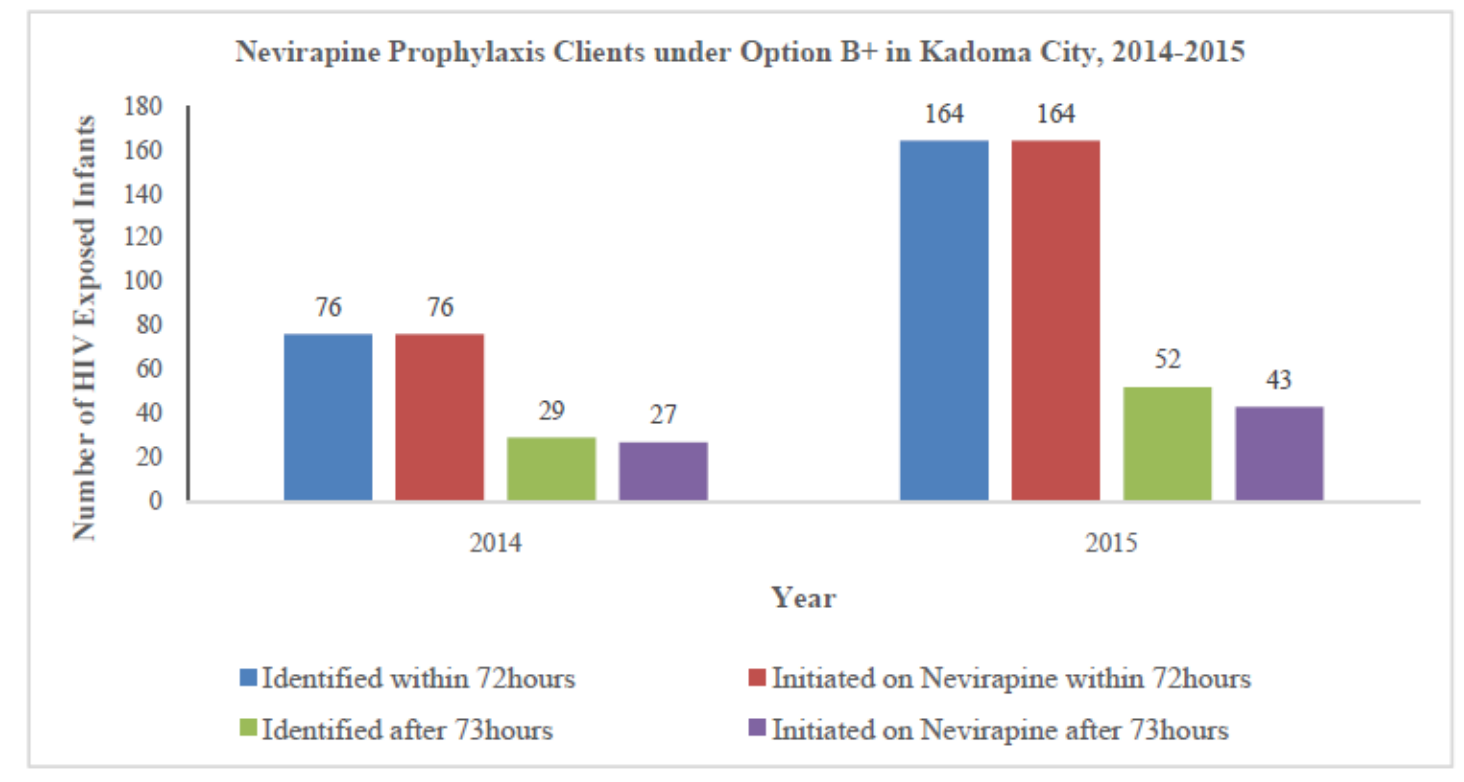

Figure 2: Nevirapine Prophylaxis Clients under Option B+ in Kadoma City, 2014-2015 
Texila American University Critchlow, Woolford Avenue, Georgetown, Guyana, South America.

Telephone: (+592) 2318118/(+592) 2318111

E-mail: ejournal.assist@tau.edu.org Skype: texila.aco32

Whatsapp: +918056580933 